\title{
PENGEMBANGAN MEDIA MONOPOLI TEMATIK BERBASIS MODEL PEMBELAJARAN KOOPERATIF TIPE TWO STAY TWO STRAY PADA TEMA INDAHNYA KERAGAMAN DI NEGERIKU UNTUK SISWA KELAS IV SDN 104204 SAMBIREJO TIMUR
}

\author{
Lala Jelita Ananda, Cici Annisa \\ Surel: ljananda.84@gmail.com
}

\begin{abstract}
The purpose of this research is to produce a thematic monopoly media based on the two stay two stray cooperative learning model. The research instrument consisted of observations, interviews and questionnaires. The results showed that the assessment of media experts in stage I by validator 1 received an average score of 4.05 in the good category, and validator 2 received an average score of 4.25 in the good category. While the validation of material experts in stage I by validator 1 gets an average score of 3.50 in the good category, and validator 2 gets an average score of 4.25 in the good category. Then the assessment of the media in stage II obtained by validator 1 gets an average score of 4.50 in the excellent category, and validator 2 gets an average score of 4.70 in the very good category. In the validation of material experts in stage II by validator 1 get an average score of 4.60 categories is very good, and validator 2 get an average score of 4.66, including very good category and worthy of testing without revision. Based on the explanation above, it can be concluded that the thematic monopoly media based on the two stay two stray cooperative learning model on the theme of the beauty of diversity in my country is feasible for learning grade IV SDN 104204 Sambirejo Timur.
\end{abstract}

Keywords: educational game tools, thematic monopoly, grade IV elementary school.

\begin{abstract}
ABSTRAK
Tujuan Penelitian ini adalah menghasilkan media monopoli tematik berbasis model pembelajaran kooperatif tipe two stay two stray. Hasil penelitian menunjukkan bahwa penilaian dari ahli media pada tahap I oleh validator 1 mendapatkan rata-rata skor 4,05 kategori baik, dan validator 2 mendapatkan rata-rata skor 4,25 kategori baik. Sedangkan validasi ahli materi pada tahap I oleh validator 1 mendapatkan rata-rata skor 3,50 kategori baik, dan validator 2 mendapatkan rata-rata skor 4,25 kategori baik. Maka di peroleh penilaian media pada tahap II oleh validator 1 mendapatkan rata-rata skor 4,50 kategori sangat baik, dan validator 2 mendapatkan rata-rata skor 4,70 kategori sangat baik. Pada validasi ahli materi pada tahap II oleh validator 1 mendapatkan rata-rata skor 4,60 kategori sangat baik, dan validator 2 mendapatkan rata-rata skor 4,66 termasuk kategori sangat baik dan layak uji coba tanpa revisi. Berdasarkan penjelasan di atas maka dapat disimpulkan bahwa media monopoli tematik berbasis model pembelajaran kooperatif tipe two stay two stray pada tema indahnya keragaman di negeriku layak untuk pembelajaran siswa kelas IV SDN 104204 Sambirejo Timur.
\end{abstract}

Kata Kunci: Alat Permainan Edukatif, Monopoli Tematik, Kelas IV SD 


\section{PENDAHULUAN}

Belajar merupakan suatu proses yang kompleks yang terjadi pada diri setiap orang sepanjang hidupnya. Apabila proses belajar itu diselenggarakan secara formal di sekolah, tidak lain dimaksudkan untuk mengarahkan perubahan pada diri siswa secara terencana dengan baik dan dalam suatu proses belajar mengajar, dua unsur yang amat penting adalah metode mengajar dan media pembelajaran. Kedua aspek ini saling berkaitan. Pemilihan salah satu metode mengajar tertentu akan memengaruhi jenis media pembelajaran yang sesuai, sehingga dapat mencapai tujuan pembelajaran yang telah direncanakan. Sejalan dengan pendapat Ananda \& Nuraini (2019:9) Media merupakan suatu unit pembelajaran lengkap yang berdiri sendiri dan terdiri atas suatu rangkaian kegiatan belajar yang disusun untuk membantu isi belajar mencapai sejumlah tujuan yang telah dirumuskan secara khusus dan jelas. Sehingga perancangan ataupun penerapan metode dan media pembelajaran pada proses pembelajaran merupakan hal yang sangat penting diperhatikan guru.

Adapun fakta di lapangan berbanding terbalik dengan apa yang seharusnya, hal ini dilihat berdasarkan hasil observasi awal yang dilaksanakan di SD Negeri 104204 Sambirejo Timur, seperti minimnya media pembelajaran dan tidak tersedianya media pembelajaran yang berorientasi bermain sambil belajar serta cenderung menggunakan media berbahan dasar dari kertas sebagai alat bantu proses belajar yang digunakan guru dalam menyampaikan materi pembelajaran dan dari segi proses belajar mengajar, guru cenderung menggunakan metode ceramah sehingga proses pembelajaran masih berpusat kepada guru sedangkan pada proses belajar mengajar yang diharapkan pada kurikulum 2013 ialah berpusat pada peserta didik. Selain itu, guru hanya mengacu pada modul tematik yang diperoleh dari pemerintah, sementara pada modul tematik, materi yang dijelaskan atau dipaparkan kurang luas dan cenderung untuk pembelajaran mandiri, sehingga interaksi keaktifan antar peserta didik kurang terwujud, sedangkan peran aktif dalam kurikulum 2013 pada pembelajaran tematik tidak hanya aktif dalam ilmu pengetahuan tetapi juga pada aspek interaksi sosial antar peserta didik. Hal itu sejalan dengan pendapat Bell (dalam Majid, 2017: 83) pada akhir proses belajar, pengetahuan akan dibangun sendiri oleh anak melalui pengalamannya dari hasil interaksi dengan lingkungnya.

Di SDN 104204 Sambirejo Timur khususnya kelas IV, penggunaan media berbasis model pembelajaran masih minim dilakukan sehingga peneliti berupaya untuk memperbaiki proses belajar agar peserta didik menjadi aktif dalam kegiatan pembelajaran, salah satunya ialah dengan menggunakan media APE (Alat Permainan Edukatif) 
berupa pengembangan media monopoli tematik, hal ini dikarenakan pola awal dari pengembangan media monopoli ini mengacu pada karakteristik peserta didik sekolah dasar yang suka bermain. Sesuai dengan (Depdikbud, 1995: 1-2) bahwa guru perlu memperhatikan beberapa prinsip latar, prinsip belajar sambil bekerja, prinsip belajar sambil bermain, dan prinsip keterpaduan.

Alat permainan monopoli ini mengutip rancangan materi sesuai dengan pembelajaran tematik, yang mana media monopoli tematik ini termotivasi dari permainan monopoli biasa yang disukai anak-anak sekolah dasar, dan bentuk fisik monopoli tematik dirancang seperti papan catur yang dapat dilipat dengan tujuan agar dapat menyimpan komponen dari alat permainan. Selain penggunaan media, hal pendukung lainnya adalah pengunaan model pembelajaran yang digunakan pada saat proses pembelajaran berlangsung. Salah satu model pembelajaran yang dapat digunakan sesuai dengan konsep pembelajaran kurikulum 2013 ialah model pembelajaran kooperatif, hal ini dikarenakan aktivitas pembelajaran kooperatif menekankan pada kesadaran peserta didik untuk saling membantu mencari dan mengolah informasi dengan tujuan pembelajaran kooperatif yang perlu dicapai adalah: a) penguasaan pengetahuan akademik; b) penerimaan terhadap keragaman; c) pengembangan keterampilan sosial. Salah satu model pembelajaran kooperatif yang cocok ialah model pembelajaran kooperatif tipe two stay two stray (TS-TS), karena model pembelajaran ini dapat digunakan dalam semua mata pelajaran dan untuk semua tingkatan usia peserta didik. Model pembelajaran two stay two stray (TS-TS) dikembangkan oleh Spancer Kagan, model pembelajaran two stay two stray (TSTS) merupakan sistem pembelajaran kelompok dengan tujuan agar peserta didik dapat saling bekerja sama, bertanggung jawab, saling membantu memecahkan masalah, dan saling mendorong satu sama lain untuk berprestasi. Model ini juga melatih peserta didik untuk bersosialisasi dengan baik dan menghargai pendapat teman-temannya. Model pembelajaran ini juga membuat peserta didik aktif dan melatih keberanian peserta didik untuk mengeluarkan pendapatnya.

Proses pembelajaran dengan pengembangan media monopoli tematik berbasiskan model pembelajaran kooperatif tipe two stay two stray ini menarik dan menyenangkan serta dapat merangsang minat belajar dan sikap antusias peserta didik. Selain itu permainan ini juga memberikan pemahaman kembali atau melakukan fungsi perulangan kepada siswa dengan menggunakan kartu-kartu yang berisi materi.

\section{METODE PENELITIAN}

Jenis penelitian ini merupakan jenis penelitian Research and Development (R\&D) atau yang disebut dengan penelitian dan pengembangan yaitu 
metode penelitian yang digunakan untuk menghasilkan produk tertentu dengan menguji keefektifan produk tersebut.

\begin{tabular}{llr}
\multicolumn{2}{c}{ Prosedur } & \multicolumn{2}{c}{ pengembangan } \\
dalam penelitian ini adalah \\
mengadopsi pada langkah-langkah \\
atau prosedur & Research and \\
Development & (R\&D) yang
\end{tabular}
dikemukakan Borg dan Gall. Dalam pengembangan media monopoli tematik berbasis model pembelajaran kooperatif tipe two stay two stray pada tema indahnya keragaman di negeriku ini langkah-langkah yang peneliti gunakan hanya sampai pada tahap penyempurnaan produk akhir karena media yang peneliti kembangkan hanya untuk mengembangan media monopoli tematik berbasis model pembelajaran kooperatif tipe two stay two stray yang layak.

Penelitian ini dilakukan di SD Negeri 104204 Sambirejo Timur. Jalan sempurna kec. Percut Sei Tuan Kab. Deli Serdang. Penelitian dilakukan pada semester genap pada tanggal 10 februari - 10 April tahun ajaran 2019/2020. Uji ahli digunakan untuk menilai tingkat kelayakan produk media pembelajaran sebelum digunakan. Subjek uji coba dalam penelitian pengembangan monopoli tematik adalah orang yang berkompeten dibidangnya yaitu ahli media dan ahli materi. Ahli media dalam hal ini adalah dosen Pendidikan yang biasa menangani dalam hal media pembelajaran. Sedangkan ahli materi merupakan dosen PGSD untuk mengetahui kesusaian materi dengan produk media pembelajaran.

Data-data yang diperoleh berdasarkan validasi dan uji coba dalam Pengembangan media monopoli tematik ini berupa data kuantitatif. Data kuantitatif merupakan data pokok berupa angkaangka sebagai hasil penilaian dari subjek uji coba kepada produk yang dikembangkan dengan tujuan untuk memberikan penilaian atau masukan untuk merevisi produk media pembalajaran yang dikembangankan.

\begin{tabular}{llr}
\multicolumn{2}{c}{ Langkah-langkah } & dalam \\
mengembangkan & instrumen angket \\
dilakukan & pada penelitian \\
pengembangan & media & monopoli
\end{tabular}
tematik yang bertema "Indahnya Keragaman Di Negeriku" kelas IV SD Negeri 104204 Sambirejo Timur adalah (1) mengembangkan kisi-kisi instrumen, (2) mengkonsultasikan kisi-kisi intrumen dengan para ahli baik ahli media maupun ahli materi, (3) menyusun dan melengkapi instrumen yang telah mendapatkan pertimbangan ahli.

Lembar instrumen yang digunakan dalam penelitian ini adalah lembar instrumen validasi ahli materi, instrumen validasi ahli media dan lembar instrumen untuk peserta didik. Instrumen tersebut digunakan sebagai dokumentasi kelayakan media pembelajaran yang dikembangkan dalam penelitian ini. Instrumen berisi pertanyaan yang berkaitan dengan media pembelajaran sebagai dasar penilaian kelayakan ahli media, ahli materi dan peserta didik. Berikut ini merupakan kisi-kisi instrumen 
pengembangan media monopoli tematik untuk pembelajaran tematik peserta didik kelas IV SD Negeri 104204 Sambirejo Timur yang ditujukan kepada ahli materi ditinjau dari isi materi dan penyajian materi.

Menurut Patton dalam Hasan (2008: 29), analisis data adalah proses mengatur urutan data, mengorganisasikannya kedalam suatu pola, kategori, dan satuan uraian dasar. Analisis data mencakup seluruh kegiatan mengklarifikasi, menganalisa, memakai dan menarik kesimpulan dari semua data yang terkumpul dalam tindakan. Teknik analisis data yang digunakan untuk mengolah data yang diperoleh dalam pengembangan media monopoli tematik yang bertema "Indahnya Keragaman Di Negeriku" adalah deskriptif kuantitatif. Analisis deskriptif kuantitatif dihasilkan dari data yang diperoleh dari angket uji ahli, uji lapangan awal, uji lapangan utama, dan uji lapangan operasional.

\section{HASIL PENELITIAN DAN PEMBAHASAN}

SD Negeri 104204 Sambirejo Timur terletak di Jl. Sempurna Kec. Percut Sei Tuan Kab. Deli Serdang. Sekolah tersebut memiliki 8 ruang kelas, perpustakaan, 1 ruang UKS, 1 ruang Musholla, 1 kantor guru dan kantor kepala sekolah serta memiliki halaman yang luas. Adapun kelas yang dipilih untuk diteliti adalah kelas IV-B dengan jumlah peserta didik 24 orang. Penelitian ini dilakukan pukul 13.30 sampai pukul 17.00 Wib sesuai jadwal pembelajaran. Sarana prasarana yang ada di dalam kelas terdiri dari papan tulis, lemari, spidol, penghapus, meja guru dan peserta didik, kursi guru dan peserta didik serta berbagai media gambar di dalam kelas.

Penelitian dan pengumpulan data dilakukan melalui observasi dan wawancara kepada guru dan peserta didik di SD Negeri 104204 Sambirejo Timur untuk mendapatkan informasi awal mengenai kendala pembelajaran yang ada. Observasi dilakukan dengan mengamati langsung proses kegiatan belajar mengajar. Sementara wawancara dilakukan pada guru kelas VI-B yaitu Ibu Sumarni, S.Pd., mengenai proses pembelajaran, media pembelajaran yang digunakan, kendala dalam pembelajaran, dan karakter subjek penelitian.

Setelah mengumpulkan data yang didapat melalui wawancara kepada pendidik kemudian ditunjang informasi baik dari buku, jurnal maupun internet, tahap selanjutnya yaitu melakukan perencanaan produk media pembelajaran. Tahap perencanaan ini merupakan lanjutan dari hasil penelitian awal dalam rangka memecahkan permasalahan yang ada. Dari hasil penelitian awal ditemukan beberapa permasalahan yang ada di SD Negeri 104204 Sambirejo Timur.

Media pembelajaran tema 7 Indahnya Keragaman Di Negeriku pada siswa SD Negeri 104204 Sambirejo Timur kelas IV telah selesai dikembangkan oleh peneliti. Produk yang dikembangkan dalam penelitian ini adalah alat permainan 
Lala Jelita Ananda, Cici Annisa : Pengembangan Media ...

edukatif monopoli tematik untuk media pembelajaran tematik integrative. Penelitian pengembangan produk ini dilakukan dengan melakukan pengumpulan informasi, desain produk, uji validasi, dan uji lapangan

Tujuan yang hendak dicapai dalam pengembangan produk ini yakni menghasilkan media pembelajaran yang inovatif dan layak untuk pembelajaran. Kelayakan produk dijaring dengan menggunakan instrumen angket yang di dalamnya terdapat catatan komentar, saran dan kritik. Penilaian angket diperoleh dari hasil penilaian ahli materi, ahli media dan siswa kelas IV SD Negeri 104204 Sambirejo Timur sebagai subjek uji coba dan pengguna produk. Pengembangan media pembelajaran berupa monopoli tematik ini disajikan dengan tampilan yang menarik pada setiap kartu yang terkait dengan materi, sehingga dapat menarik perhatian peserta didik dalam belajar. Produk yang dikembangkan oleh peneliti diharapkan dapat membantu peserta didik agar lebih aktif didalam kelas.

Hasil penilaian validator ahli materi tahap I dan tahap II dapat dilihat pada diagram berikut :

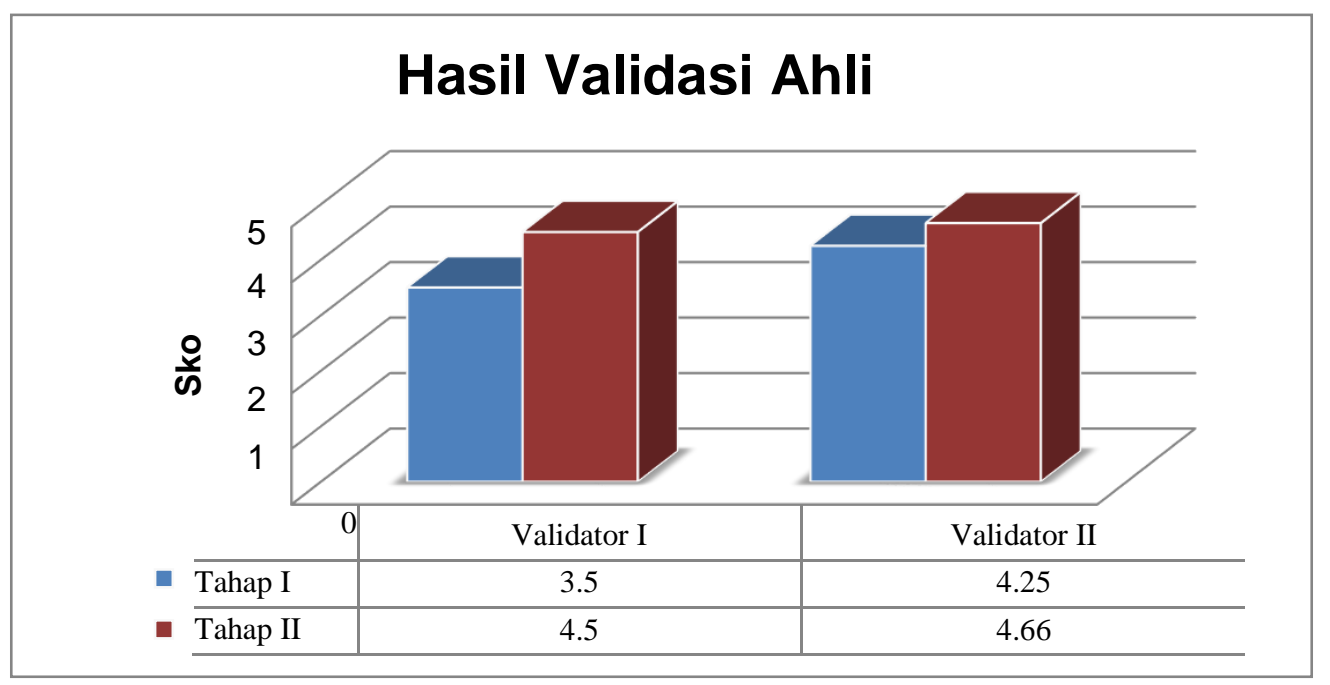

Gambar 1. Diagram Hasil Validasi Ahli Materi Tahap I dan Tahap II

Berdasarkan diagram diatas dapat disimpulkan bahwa penilaian pengembangan media pembelajaran monopoli tematik dilakukan oleh dua ahli materi yakni dua dosen PGSD FIP Universitas Negeri Medan. Pada validasi ahli materi tahap I memperoleh penilaian dengan kategori "Baik". Ada saran yang diberikan oleh validator yaitu memperbaiki perumusan indikator dan tujuan pembelajaran pada RPP yang dibuat peneliti. Pada validasi tahap II memperoleh penilaian dengan kategori "Sangat Baik" atau "Layak". Pada tahap ini ahli materi menyatakan bahwa media monopoli tematik yang dikembangkan sudah tidak ada bagian 
yang harus diperbaiki sehingga sudah

dan dapat

diuji cobakan.

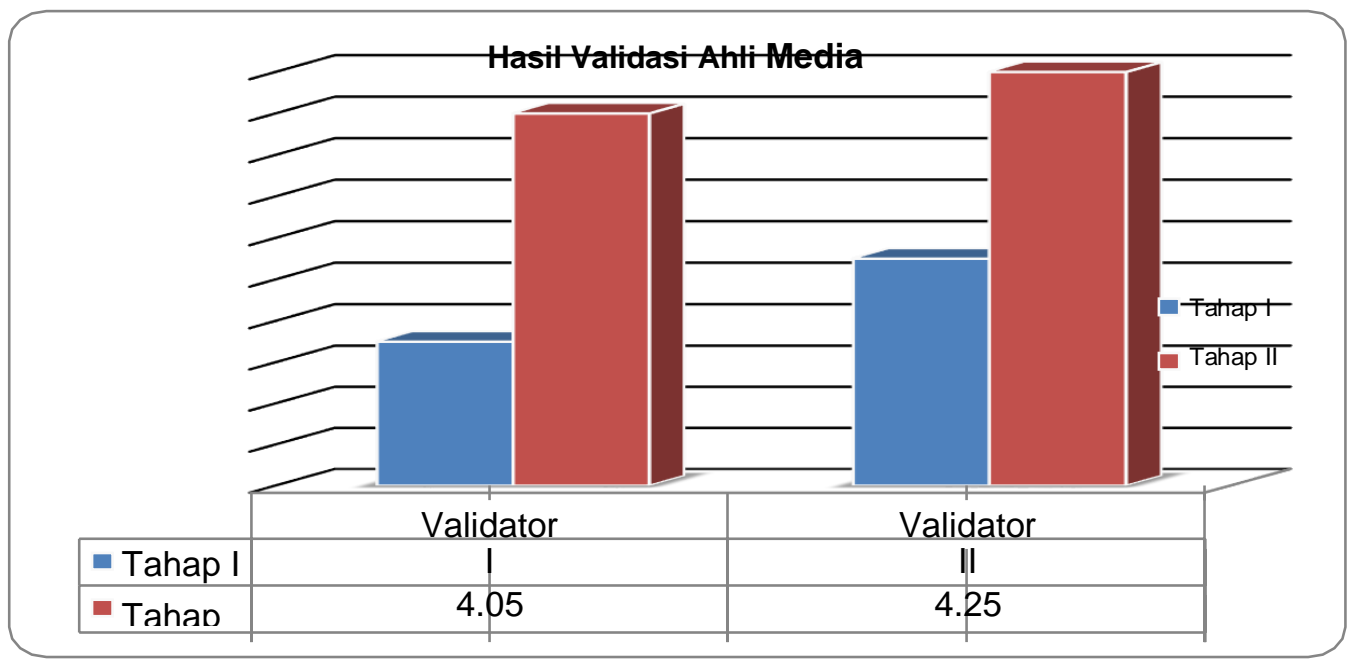

\section{Gambar 2. Diagram Hasil Penilaian Ahli Media Tahap I dan Tahap II}

Berdasarkan diagram di atas dapat disimpulkan bahwa penilaian pengembangan media pembelajaran berupa monopoli tematik dilakukan oleh dua ahli media yang mana dilakukan sebanyak 2 kali. Pada validasi ahli media tahap I memperoleh penilaian dengan kategori "Baik" atau "Layak" untuk di uji cobakan dengan revisi berdasarkan kritik dan saran dari validator. Ada beberapa bagian yang harus diperbaiki, diantaranya (1) Pion harus berwarna warni dan ukuran harus diperkecil, (2) Dadu harus memiliki wadah agar peserta didik lebih mudah menggunakannya, (3) Sesuaikan ukuran kartu dengan ukuran kotak pada papan permainan monopoli, (4) Buku panduan sebaiknya diberi hardcover agar buku panduan tidak mudah rusak, (5) diperlukan benda sebagai penanda petak hak milik, (6) diperlukan wadah kartu yang lebih kokoh. Tahap II penilaian media mengalami peningkatan karena memperoleh penilaian dengan kategori "Sangat Baik" atau "Layak". Pada tahap ini ahli media menyatakan bahwa media monopoli tematik yang dikembangkan sudah tidak ada bagian yang harus diperbaiki sehingga sudah layak untuk digunakan tanpa revisi dan dapat diuji cobakan kepada peserta didik.

Tahap uji coba peneliti melakukan tiga tahap uji coba yaitu uji coba lapangan awal, uji coba lapangan utama dan uji coba lapangan dengan operasional sebanyak 10 indikator penilaian. Hasil uji coba media monopoli tematik dapat dilihat pada tabel berikut: 
Lala Jelita Ananda, Cici Annisa : Pengembangan Media ...

\section{Pembahasan}

Tabel 1. Penilaian Terhadap Uji Coba I, II dan III

\begin{tabular}{c|ll|c|c|c|c}
\hline No. & \multicolumn{2}{|c|}{ Tahap Uji Coba } & $\sum \mathbf{x}$ & $\begin{array}{c}\text { Skor } \\
\text { Maks }\end{array}$ & Persentase & Kategori \\
\hline 1. & Uji $\begin{array}{l}\text { Coba } \\
\text { Lapangan }\end{array}$ & 34 & 40 & $85,00 \%$ & Layak \\
\hline 2. & Uwji $\quad \begin{array}{ll}\text { Coba } \\
\text { Lapangan }\end{array}$ & 75 & 80 & $93,7 \%$ & Layak \\
\hline 3. & $\begin{array}{l}\text { Uji Coba } \\
\text { Pelaksanaan }\end{array}$ & 234 & 240 & $97,5 \%$ & Layak \\
\hline
\end{tabular}

Untuk lebih jelasnya presentase tematik terhadap peserta didik di atas penilaian uji coba media monopoli dapat dilihat pada diagram berikut :

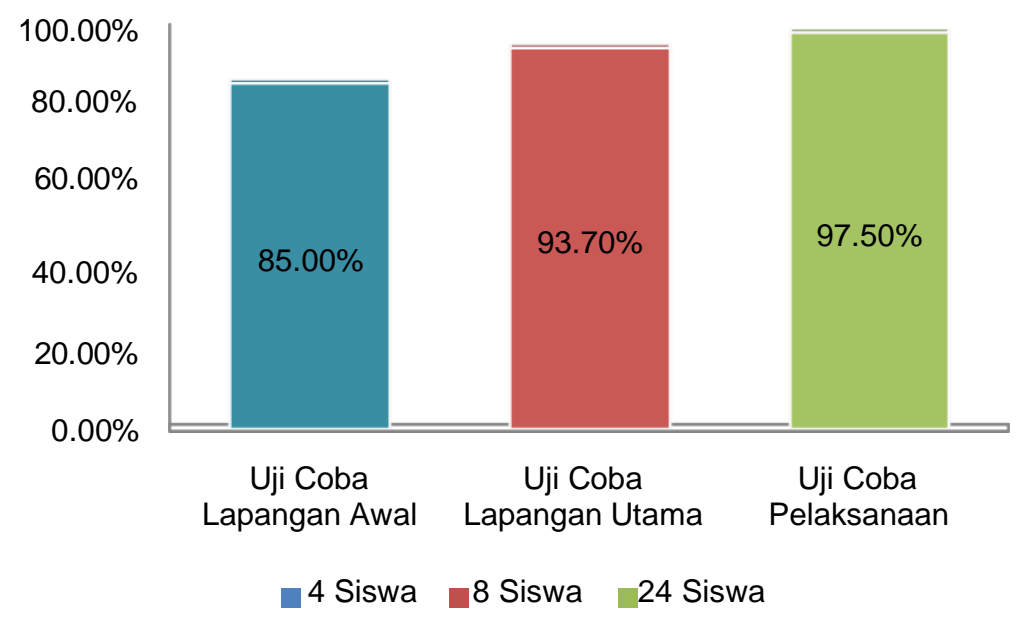

\section{Gambar 3. Diagram Hasil Penilaian Uji Coba Peserta Didik}

Berdasarkan diagram di atas uji coba lapangan operasional ini mendapatkan respon sangat baik. Siswa sangat tertarik dan senang terhadap media pembelajaran tersebut. Hal ini terlihat dari komentar- komentar mereka saat menjawab soal-soal yang ada dalam permainan tersebut ditambah lagi berdasarkan hasil dari instrument yang diberikan kepada peserta didik setelah melakukan pembelajaran. Tanggapan peserta didik dari ketiga tahap memiliki respon yang baik tentang media pembelajaran berupa monopoli tematik materi tema 7 Indahnya Keragaman Di Negeriku pada peserta didik Kelas VI SD Negeri 104204 Sambirejo Timur. Yang menjadi perbedaan penelitian ini dan penelitian sebelumnya adalah di mana pada penelitian sebelunya 
yang berjudul media monopoli kotak hitung oleh Budi Adi Prayogo yakni Media yang dikembangkan hanya terfokus pada mata pelajaran Matematika materi Hitung, dan Komponen terdiri dari papan monopoli dengan petak 8 × 8 , kartu hak milik, kartu peluang, kartu dana umum, uang mainan, pion, 2 dadu. sedangkan media monopoli yang dikembangkan oleh peneliti adalah media yang dikembangkan untuk pembelajaran tematik tema 7 "Indahnya. Keragaman Dinegeriku" dan Komponen terdiri dari papan monopoli dengan petak 9 × 9, kartu hak milik, kartu peluang (kesempatan), kartu iuran sekolah (dana umum), kartu soal/kartu materi, wadah kartu, pion, 1 dadu berbentuk segi lima sama sisi dengan 12 sisi, wadah dadu yang dapat dilipat, buku peraturan permainan, uang mainan, dan miniatur rumah sebagai penanda. Adapun kendala dalam pelaksanaan penelitian ini adalah diperlukan waktu yang tidak sedikit untuk siswa mendiskusikan materi pelajaran dan pada kegiatan pelaksanaan memerlukan waktu yang panjang.

\section{SIMPULAN}

Pada penelitian dan pengembangan media pembelajaran berupa monopoli tematik berbasis model pembelajaran two stay two stray pada tema 7 Indahnya Keragaman Di Negeriku kelas IV SD Negeri 104204 Sambirejo Timur telah selesai dilakukan dan dibahas sesuai pada hasil penelitian dan pengembangan dengan kesimpulan sebagai berikut :

- Media pembelajaran berupa monopoli tematik tema 7 Indahnya Keragaman Di Negeriku pada siswa kelas IV SD Negeri 104204 Sambirejo Timur yang telah dikembangkan dan diujikan melalui angket validasi media dan materi bahwa penilaian dari ahli media pada tahap I oleh validator 1 mendapatkan rata-rata skor 4,05 termasuk kategori layak, dan validator 2 mendapatkan ratarata skor 4,25 termasuk kategori layak. Sedangkan validasi ahli materi pada tahap I oleh validator 1 mendapatkan ratarata skor 3,50 termasuk kategori layak, dan validator 2 mendapatkan rata-rata skor 4,25 termasuk kategori layak. Dengan nilai Uji coba lapangan awal dengan rata-rata skor $85 \%$.

- Media pembelajaran berupa monopoli tematik tema 7 Indahnya Keragaman Di Negeriku pada siswa kelas IV SD Negeri 104204 Sambirejo Timur yang telah dikembangkan dan diujikan melalui angket validasi media dan materi Setelah melakukan perbaikan pada media dan materi pada tahap I. Maka di peroleh penilaian media pada tahap II oleh validator 1 mendapatkan rata-rata skor 4,50 termasuk kategori layak, dan validator 2 mendapatkan rata-rata skor 4,70 termasuk kategori layak. 
Sedangkan validasi ahli materi pada tahap II oleh validator 1 mendapatkan rata-rata skor 4,60 termasuk kategori layak, dan validator 2 mendapatkan ratarata skor 4,66 termasuk kategori layak. Dengan uji coba lapangan utama kepada 8 peserta didik memperoleh rata-rata skor 93,7\% kemudian uji coba pelaksanaan kepada 24 peserta didik memperoleh rata-rata skor $97,5 \%$.

\section{DAFTAR RUJUKAN}

Abdullah, Sani. 2015. Inovasi Pembelajaran. Jakarta: Bumi Aksara.

Ananda, Lala Jelita dan Nuraini. 2019. "Pengembangan Media Pembelajaran Berbasis Multimedia Interaktif Dengan Pendekatan Saintifik Pada Tema Indahnya Keragaman Di Negeriku Di Kelas IV SD Negeri 101969 Tanjung Purba”. Jurnal SEJ (School Education Journal), Unimed, Volume 9, Nomor 1.

Arsyad, Azhar. 2013. Media Pembelajaran. Jakarta: Raja Grafindo Persada.

C. Asri Budiningsih. 2015. Belajar dan Pembelajaran. Jakarta: Rineka Cipta.

Djam'an Satori, Aan Komariah. 2011. Metodologi Penelitian

Lie, Anita. 2007. Coperative Learning: memperaktikkan coperative learning di ruangruang kelas. PT garasindo.
Majid, Abdul. 2017. Pembelajaran Tematik Terpadu. Bandung: PT Remaja Rosdakarya.

Mujib, Fathul dan Nailur rahmawati. 2011. Metode PermainanPermaianan Edukatif Dalam Belajar Bahasa Arap. Yogyakarta: Diva Press.

Noor, Juliansyah. 2011. Metodologi Penelitian. Jakarta: Prenada Media Group.

Prastowo, Andi. 2019. Analisis Pembelajaran Tematik Terpadu. Jakarta: Pranamedia Group.

Sudjana, Nana \& Ahmad Rivai. 2010. Media Pengajaran. Bandung: Sinar Baru Algensindo.

Sukmadinata, Nana Syaodih. 2011. Prosedur Penelitian Pendidikan. Bandung: PT. Remaja Rosdakarya.

Sugiyono. 2015. Metode Penelitian Kuantitatif, Kualitatif dan $R \& D$. Bandung: Afabeta.

Shoimin, Aris. 2018. 68 Model Pembelajaran Inofatif Dalam Kurikulum 2013. Yogyakarta: Ar- Ruzz Media.

Sukirman. 2018. Pengembangan Media Pembelajaran. jakarta: Rajawali pers.

Yusuf, Syamsu dan M. Nani Sugandhi. 2013. Perkembangan perserta didik. Bandung: PT. Rajagrafindo Persada.

Zaini, Hisyam, dkk. 2016. Strategi Pembelajaran Aktif. Yogyakarta: Pustaka Insan Mandiri. 